\title{
KARAKTERISTIK IBU DENGAN BALITA BERAT BADAN DI BAWAH GARIS MERAH (BGM) DI WILAYAH KERJA PUSKESMAS INGIN JAYA ACEH BESAR
}

\author{
Characteristics Of Mother And Body Weight Under The Red Line (Bgm) In \\ The Working Area Of Puskesmas Want Jaya Aceh Besar \\ Zulfahmi*1, Eva warni $^{2}$ \\ ${ }^{1,2}$ Fakultas Ilmu Kesehatan, Universitas Ubudiyah Indonesia, Banda Aceh \\ Email: zulfahmi@uui.ac.id ${ }^{* 1}$, evawarni13@yahoo.com²
}

\begin{abstract}
ABSTRAK
Anak di bawah lima tahun (balita) dan pra sekolah merupakan kelompok yang menunjukkan pertumbuhan badan yang pesat, sehingga memerlukan zat-zat gizi yang tinggi disetiap kilogram berat badannya. Anak balita ini justru merupakan kelompok umur yang paling sering menderita akibat kekurangan gizi (Paath, 2005). Survei awal diperoleh di Wilayah Kerja Puskesmas Ingin Jaya Aceh Besar jumlah balita yang berat badan di Bawah Garis Merah (BGM) 76 orang. Dari hasil wawancara dengan 6 orang ibu yang mempunyai balita BGM terdapat 4 dari 6 balita yang BGM berasal dari keluarga yang berpendidikan rendah, pendapatan keluarganya kurang dan laju kelahiran (paritas) Ibu tinggi. Penelitian ini bertujuan untuk mengetahui Karakteristik Ibu yang berat badan balitanya berada di Bawah Garis Merah (BGM) ditinjau dari pendidikan ibu, pendapatan keluarga dan paritas. Desain penelitian ini bersifat deskriptif dengan pendekatan Cross Sectional, populasi dalam penelitian ini adalah Ibu yang mempunyai balita BGM di Wilayah Kerja Puskesmas Ingin Jaya Aceh Besar, dengan jumlah sampel 43 orang Ibu. Tehnik pengambilan sampel dalam penelitian ini adalah Porposive Sampling. Berdasarkan hasil penelitian dapat disimpulkan bahwa balita yang berat badan BGM sebagian besar berasal dari keluarga yang berpendidikan rendah yaitu sebanyak 51,2 \%, Presentase pendapatan keluarga yang mempunyai balita berat badan BGM juga tidak sesuai dengan UMP (kurang) yaitu sebesar 74,4\%. Sedangkan paritas ibu yang mempunyai balita berat badan BGM lebih besar berasal dari kategori multipara yaitu mencapai $62,8 \%$. Diharapkan kepada petugas kesehatan untuk dapat meningkatkan keadaan gizi anak balita ke arah yang lebih baik melalui penyuluhan dan pengolahan makanan sederhana menjadi menu yang seimbang sehingga dapat meminimalisasi kasus BGM yang sedang terjadi sekarang ini, yang pada akhirnya dapat mewujudkan balita sehat di masa yang akan datang.
\end{abstract}

\section{Kata Kunci : Karakteristik Ibu, Balita BGM, Pendidikan, Pendapatan, Paritas}

\begin{abstract}
Children under five years old (toddlers) and pre-school are groups that show rapid body growth, so that they need high nutrients in every kilogram of body weight. This toddler is precisely the age group that most often suffers due to malnutrition (Paath, 2005). The initial survey was obtained in the Working Area of the Puskesmas of Want Jaya Aceh, with a total of 76 underweight children (BGM) underweight. From interviews with 6 mothers who have BGM infants there are 4 out of 6 infants whose BGM comes from families with low education, low family income and high birth rate (parity). This study aims to determine the Characteristics of Mothers whose toddler weight is below the Red Line (BGM) in terms of maternal education, family income and parity. The design of this research is descriptive with Cross Sectional approach, the population in this study is mothers who have toddlers BGM in the working area of the Health Center of Want Jaya Aceh Besar, with a sample of 43 mothers. The sampling technique in this study is Porposive Sampling. Based on the results of the study it can be concluded that toddlers with BGM weight are mostly from
\end{abstract}


low-educated families as much as $51.2 \%$. Whereas parity of mothers who have children under five years of age greater BGM comes from the multipara category which reached $62.8 \%$. It is expected that health workers can improve the nutritional status of children under five to a better direction through counseling and simple food processing into a balanced menu so as to minimize the current cases of BGM, which in turn can realize healthy toddlers in the future.

\section{Keywords: Mother's Characteristics, Toddler BGM, Education, Income, Parity}

\section{PENDAHULUAN}

Salah satu prioritas pembangunan nasional dibidang kesehatan adalah upaya perbaikan gizi yang berbasis pada sumber daya kelembagaan dan budaya lokal. Kurang gizi akan berdampak pada penurunan kualitas SDM (Sumber Daya Manusia) yang lebih lanjut dapat berakibat pada kegagalan pertumbuhan fisik, perkembangan mental dan kecerdasan, menurunkan produktivitas, meningkatkan kesakitan dan kematian. Visi pembangunan gizi adalah "mewujudkan keluarga sadar gizi untuk mencapai status gizi masyarakat dan keluarga yang optimal" (Adisasmito, 2008).

Kekurangan zat gizi secara umum (makanan kurang dalam kualitas dan kuantitas) menyebabkan gangguan pada proses pertumbuhan, produksi tenaga pertahanan tubuh, struktur dan fungsi otak dan perilaku anak yang kurang gizi tersebut (Almatsier, 2003).

Kesepakatan global yang dituangkan dalam Millenium Development Goals (MDGs) yang terdiri dari 8 tujuan, 18 target, dan 48 indikator menegaskan bahwa tahun 2015 setiap negara menurunkan kemiskinan dan kelaparan separuh dari kondisi pada tahun 1990. Dua dari lima indikator sebagai penyebaran tujuan pertama Millenium Development Goals adalah menurunkan prevalensi gizi kurang pada anak balita (indikator ke empat) dan menurunnya jumlah penduduk dengan defisit energi (indikator ke lima). (Adisasmito, 2008).

Hasil survei awal yang telah saya lakukan dengan 6 orang responden dapat disimpulkan bahwa 4 dari 6 balita yang berat badan di Bawah Garis Merah (BGM) berasal dari keluarga yang berpendidikan rendah, pendapatan keluarganya kurang serta ibu yang paritasnya tinggi, hal ini sesuai dengan teori Suhardjo (2003).

Berdasarkan data Dinas Kesehatan Provinsi Aceh (2009) didapatkan jumlah balita keseluruhan 429.811 balita, yang tidak melakukan penimbangan

201.640 balita (46.91\%), yang melakukan penimbangan 228.171 balita $(53,09 \%)$, yang berat badannya naik 153.639 balita $(67,34 \%)$ sedangkan berat badan yang berada di Bawah Garis Merah (BGM) mencapai 9.214 balita (4,04\%) dan yang mengalami gizi buruk berjumlah 1.091 balita (0,48\%). Data dari Dinas Kesehatan Aceh Besar 
Journal of Healthcare Technology and Medicine Vol. 4 No. 2 Oktober 2018

Universitas Ubudiyah Indonesia

e-ISSN : 2615-109X

(2011) didapatkan balita yang berat badannya di Bawah Garis Merah (BGM) berjumlah 1.009 orang $(3,17 \%)$ dari

31.735 balita yang ada, dari data tersebut dapat dilihat bahwa presentase balita yang berat badan di Bawah Garis Merah (BGM) sangat tinggi.

\section{METODE PENELITIAN}

Jenis penelitian ini bersifat deskriptif dengan pendekatan Cross sectional, dimana penelitian ini untuk mengetahui Karakteristik Ibu dengan Balita Berat Badan di Bawah Garis Merah di Wilayah Kerja Puskesmas Ingin Jaya Aceh Besar.

Populasi dalam penelitian ini adalah semua Ibu yang mempunyai Balita yang Berat Badannya di Bawah Garis Merah di Wilayah Kerja Puskesmas Ingin Jaya yang berjumlah sebanyak 76 orang ibu.

sendiri, berdasarkan ciri-ciri dan sifat-sifat serta kriteria tertentu, adapun kriteria yang terdapat dalam penelitian ini yaitu :

a. Bersedia jadi responden b.

Bisa baca dan tulis

c. Ada ditempat pada saat penelitian

\section{HASIL DAN PEMBAHASAN}

\section{Pendidikan Ibu}

Pendidikan responden yang mempunyai balita berat badan di Bawah Garis Merah (BGM) di Wilayah Kerja Puskesmas Ingin Jaya Aceh Besar dapat dilihat pada tabel dibawah ini :

Tabel 1

Distribusi Frekwensi Pendidikan Ibu yang Mempunyai Balita Berat Badan Di Bawah Garis Merah (BGM) Di Wilayah Kerja Puskesmas Ingin Jaya Aceh Besar Tahun 2011

\begin{tabular}{|c|l|c|c|}
\hline No & Pendidikan Ibu & Frekwensi & Persentase (\%) \\
\hline 1 & Dasar & 22 & $51,2 \%$ \\
2 & Menengah & 14 & $32,6 \%$ \\
3 & Tinggi & 7 & $16,3 \%$ \\
\hline & Jumlah & 43 orang & $100 \%$ \\
\hline
\end{tabular}

Dari hasil penelitian yang dilakukan dengan 43 orang responden di Wilayah Kerja Puskesmas Ingin Jaya Aceh Besar, diperoleh bahwa Pendidikan Ibu yang mempunyai balita berat badan di Bawah Garis Merah (BGM) adalah berpendidikan rendah yaitu 
Journal of Healthcare Technology and Medicine Vol. 4 No. 2 Oktober 2018

Universitas Ubudiyah Indonesia

e-ISSN : 2615-109X

mencakup 22 orang responden $(51,2 \%)$, sedangkan 14 responden $(32,6 \%)$ berada pada pendidikan menengah dan 7 orang responden $(16,3 \%)$ lainnya berpendidikan tinggi. Keadaan ini menunjukkan bahwa sebagian besar responden yang mempunyai balita berat badan di bawah garis merah berpendidikan dasar. Hal ini sesuai dengan teori Suhardjo (2003) yang menyatakan bahwa keadaan gizi seorang balita di pengaruhi oleh faktor pendidikan orang tua.

Pendidikan kesehatan tentang gizi pada umumnya dapat dipahami melalui keluarga. Pentingnya gizi (dalam hal ini pangan) sebagai kebutuhan pokok dalam keluarga, harus diterapkan secara proposional, khususnya dalam kaitan pengelolaan sumber daya keluarga serta aktivitas keluarga. Bagi masyarakat yang berpendidikan dan cukup pengetahuan tentang nilai gizi lebih banyak mempergunakan pertimbangan rasional dan pengetahuan tentang nilai gizi makanan atau pertimbangan fisiologik lebih menonjol dibandingkan dengan kebutuhan kepuasan psikis (Paath, 2005).

\section{Pendapatan Keluarga}

Pendapatan Keluarga responden yang mempunyai balita berat badan di Bawah Garis Merah (BGM) di Wilayah Kerja Puskesmas Ingin Jaya Aceh Besar dapat dilihat pada tabel 5.2 berikut :

\section{Tabel 2}

Distribusi Frekwensi Pendapatan Keluarga yang Mempunyai Balita dengan Berat Badan Di Bawah Garis Merah (BGM) Di Wilayah Kerja Puskesmas Ingin Jaya Aceh Besar Tahun 2011

\begin{tabular}{|l|l|c|c|}
\hline No & Pendapatan Keluarga Perbulan & Frekwensi & Persentase (\%) \\
\hline 1 & Tinggi (sesuai dengan UMP) & 11 & $25,6 \%$ \\
2 & Rendah (tidak sesuai dengan & 32 & $74,4 \%$ \\
& UMP) & & \\
\hline & Jumlah & 43 orang & $100 \%$ \\
\hline
\end{tabular}

Berdasarkan hasil penelitian yang dilakukan pada 43 responden di Wilayah

Kerja Puskesmas Ingin Jaya Aceh Besar, diperoleh hasil bahwa pendapatan keluarga yang mempunyai balita dengan berat badan di Bawah Garis Merah (BGM) adalah rendah (tidak sesuai dengan UMP) yaitu 32 responden (74,4\%). Sedangkan 11 responden $(25,6 \%)$ lainnya berpendapatan tinggi (sesuai dengan UMP). Hal ini menunjukkan bahwa sebagian besar responden yang mempunyai balita berat badan di bawah garis merah berpendapatan di bawah UMP.

Hasil penelitian diatas sesuai dengan teori Suhardjo (2005) yang menyatakan bahwa kemiskinan sebagai penyebab gizi kurang menduduki posisi pertama pada kondisi yang umum. Hal ini harus mendapat perhatian serius karena keadaan ekonomi ini relatif 
Journal of Healthcare Technology and Medicine Vol. 4 No. 2 Oktober 2018

Universitas Ubudiyah Indonesia

e-ISSN : 2615-109X

mudah diukur dan berpengaruh besar pada konsumsi pangan, penduduk miskin biasanya menkonsumsi makanan yang lebih murah dan menu biasanya tidak (kurang) bervariasi. Sebaliknya pada penduduk berpenghasilan tinggi, umumnya mengkonsumsi makanan yang harganya lebih tinggi, akan tetapi penghasilan yang tidak menjamin tercapainya gizi yang baik.

\section{Paritas}

Paritas ibu yang mempunyai balita berat badan di Bawah Garis Merah (BGM) di Wilayah Kerja Puskesmas Ingin Jaya Aceh Besar dapat dilihat pada tabel dibawah ini :

Tabel 3

Distribusi Frekwensi Paritas Ibu yang Mempunyai Balita Berat Badan Di Bawah Garis Merah ( BGM ) Di Wilayah Kerja Puskesmas Ingin Jaya Aceh Besar Tahun 2011

\begin{tabular}{|l|l|c|c|}
\hline No & \multicolumn{1}{|c|}{ Paritas Ibu } & Frekwensi & Persentase (\%) \\
\hline 1 & Primipara & 6 & $14,0 \%$ \\
2 & Multipara & 27 & $62,8 \%$ \\
3 & Grandemultipara & 10 & $23,3 \%$ \\
\hline & Jumlah & 43 orang & $100 \%$ \\
\hline
\end{tabular}

Berdasarkan hasil penelitian yang dilakukan pada 43 responden di Wilayah Kerja Puskesmas Ingin Jaya Aceh Besar, diperoleh hasil bahwa laju kelahiran (paritas) responden yang mempunyai balita dengan berat badan di Bawah Garis Merah (BGM) kebanyakan termasuk dalam kategori multipara yaitu mencapai 62,8\% (27 responden). Sedangkan yang grandemultipara 23,3 \% (10 responden) dan 14,0 \% (6 responden) lagi termasuk dalam kategori primipara.

Keadaan tersebut sesuai dengan teori Suhardjo (2003) yang menyatakan bahwa apabila wanita melahirkan beberapa anak dan anak anak ini jaraknya dekat satu sama lain, maka terdapatlah beban tambahan pada tubuhnya. Tanpa ada waktu yang cukup diantara kehamilan, ia tak akan mampu untuk mengganti simpanan zat zat gizi didalam tubuhnya yang telah digunakan olehnya sendiri dan oleh anaknya. Dalam hal hal semacam itu, baik ibu maupun anaknya sangat peka terhadap gizi kurang.

\section{KESIMPULAN}

Berdasarkan penelitian yang telah peneliti lakukan terhadap Karakteristik Ibu yang mempunyai balita berat badan di Bawah Garis Merah (BGM) ditinjau dari 
Journal of Healthcare Technology and Medicine Vol. 4 No. 2 Oktober 2018

Universitas Ubudiyah Indonesia

e-ISSN : 2615-109X

Pendidikan Ibu, Pendapatan Keluarga dan Paritas di Wilayah Kerja Puskesmas Ingin Jaya Aceh Besar maka dapat disimpulkan sebagai berikut :

1. Balita yang berat badan di Bawah Garis Merah (BGM) lebih besar persentasenya terdapat dalam keluarga yang latar belakang pendidikan ibunya rendah (pendidikan dasar) yaitu mencapai 51,2\%.

2. Balita yang berat badan di Bawah Garis Merah (BGM) persentasenya lebih besar berasal dari keluarga yang latar belakang sosial ekonominya kurang atau pendapatan keluarganya kurang dari UMP (Upah Minimum Provinsi) yaitu mencapai 74,4 \%.

3. Balita yang berat badan di Bawah Garis Merah (BGM) persentasenya lebih

besar berasal dari ibu yang paritasnya multipara yaitu mencapai $62,8 \%$.

\section{DAFTAR PUSTAKA}

Adisasmito W, Sistem Kesehatan. Jakarta, PT Raja Grafindo Persada, 2008. Almatsier, S, Prinsip Dasar Ilmu Gizi. Jakarta, Gramedia Pustaka Utama, 2003. Arali, Penilaian Status Gizi 2008. http:// www.Google.com

Dinas Kesehatan Aceh, Profil Kesehatan Provinsi Aceh. Banda Aceh, 2009. Soegeng, et al, Kesehatan dan Gizi. Jakarta, Rineka Cipta, 2009.

Sudrajat, Konsep Pendidikan Karakter 2010. http:// www.Google.com (dikutip tanggal 20 Juni 2011).

Suhardjo, Berbagai Cara Pendidikan Gizi. Jakarta, Bumi Aksara, 1996.

Suherni et, al, Perawatan Masa Nifas. Yogyakarta, Fitramaya, 2009.

Suparyanto, Konsep Paritas/Partus. http://www.Google.com

Tirtawinata, T, Makanan Dalam Perspektif Al Quran dan Ilmu Gizi. Jakarta, Balai Penerbit FKUI, 2006.

Zuhriyah, Pengertian Karakteristik 2011. http://www.Google.com 
Journal of Healthcare Technology and Medicine Vol. 4 No. 2 Oktober 2018

Universitas Ubudiyah Indonesia

e-ISSN : 2615-109X 